\title{
Economics and Enviromental Resources: Review
}

\author{
Enwere Dike ${ }^{1} \&$ Ngozi I. Dike ${ }^{2}$ \\ ${ }^{1}$ Department of Economics, Kogi State University, Anyigba, Kogi State, Nigeria \\ ${ }^{2}$ Department of Biology, Federal College of Education, Zaria, Kaduna State, Nigeria \\ Correspondence: Enwere Dike, Professor, Department of Economics, Kogi State University, Anyigba, Kogi \\ State, Nigeria. E-mail: meidike@yahoo.com
}

Received: March 17, 2012

Accepted: October 8, 2012

Online Published: November 14, 2012

doi:10.5539/ibr.v5n12p161

URL: http://dx.doi.org/10.5539/ibr.v5n12p161

\begin{abstract}
We review the component elements of environmental resources in order to provide insights into their economic characteristics and properties. Environmental resources are the goods and services provided by the natural environment and are constituted into three categories: atmosphere; water; and land and soil. The economic literature emphasizes two points in regard to the economic characteristics of environmental resources. First, many environmental goods are renewable resources and have features of public goods-accessible to all in the community at no charge, so that excluding unwanted users is difficult, which lends them to over-exploitation to the point of extinction in many instances. Second, environmental resources constitute a kind of capital and so makes measurable contribution to output similar to the role played by physical and human capital, and so should be accounted for, invested in, and exploited efficiently.
\end{abstract}

Keywords: environmental resources, economic analysis, renewable resources, non-renewable resources, environmental accounting, sustainable development

\section{Introduction}

The natural environment referring to the conditions under which human beings, animals, and plants have to live in and reproduce themselves-has attracted heightened interest in international development discourse since the end of the 1980s. Prior to this period, the focus of interest was on economic growth and efficient resources allocation, and the engine of economic growth and development was conceived to lie in capital accumulation. By the beginning of the 1990s, as just suggested, protection of the natural environment became a major development policy objective, the concept of 'sustainable development' being evolved to capture the three key objectives of economic development: economic, social, and environmental. Global concern for the environment lay behind the 1992 United Nations 'Earth Summit' in Rio de Janeiro, Brazil, which focused on the importance of biodiversity and sustainable use of the Earth's genetic resources. Environmental problems also constitute the $7^{\text {th }}$ agenda in the Millennium Development Goals (MDGs), which require achieving sustainable development patterns and preserving the productive capacity of national ecosystems for future generations.

The central objective of the present paper is to provide insights into the nature of environmental resources, their component elements, and the way current economic literature attempts to incorporate environmental resources into analysis of national wealth. The rest of the paper is structured into six sections as follows: Section 2 provides a conceptualization of environmental resources. In section 3 the concepts of renewable and non-renewable environmental resources are examined. Sections 4 and 5, respectively, deal with the types of goods and services produced by ecosystems, and so-called environmental accounting dealing with how current literature incorporates environmental or ecological resources into national wealth. Section 6 explains the notion of sustainable development, and section 7 concludes the paper.

\section{Conceptualizing Enviromental Resources}

Abstractly conceived, environment refers to the conditions, circumstances, and influences surrounding and influencing the development of an organism or group of organisms. In our present context, the organism refers to human agents and the groups of human agents are generally communities, regions, countries, etc. On the other hand, the conditions, circumstances and influences surrounding and affecting the development of the groups of human beings is the natural environment or ecosystem with all its life-support capabilities and short-falls. Environmental resources, on the other hand, refer to the goods and services provided by the natural environment 
otherwise called ecosystem or environmental or ecological services; these may be categorized into three: (i) those derived from the atmosphere (the whole mass of air enveloping or surrounding the earth) - e.g. clean air, ozone layer, etc; (ii) those derived from water- e.g. water itself, fish, etc; and (iii) those derived from land and soil - e.g. timber, farmland, minerals etc.

Many environmental resources provide a flow of services to producers and consumers overtime. Put differently, environmental resources serve both as production inputs and final consumption goods (Cavendish, 1999). The earth's atmosphere, specifically clean air and ozone layer, is a major contributor to the sustenance of life on earth, as suggested by the dangers posed by depletion of the ozone layer and associated global warming (the effect of burning fossil fuels increasing the quantity of carbon dioxide in the atmosphere so that the earth warms up, which could cause large-scale climate changes, among other catastrophic results - see, for instance, Hamilton and Fay 2009; World Bank (2010); Bowen et al. (2010); Lombery (2009); Jones and Keen (2009); Noble and Watson (2006). Also, many of the resources found in the natural environment are renewable and have the characteristic of public goods, accessible to all at no charge, to which we return.

Indeed, the natural environment produces a wide range of economic benefits. However, early attempts at environmental resources evaluation were hampered by economists' limited and, quite often, defective knowledge not only of what constitute environmental resources 'beyond the obvious ones of timber and fish' (The Economist, $23^{\text {rd }}$ April 2005), but also the types of services provided by the ecosystems apart from difficulty of putting 'cash values' on such services. Natural scientists, biologists and ecologists particularly, however, have produced, in recent decade, abundant evidence that the natural environment produces a wide range of economic benefits. Indeed, scientists now know a great deal more than they used to about how ecosystems function, which habitats deliver which services and in what quantity those services are supplied. The World Bank publishes or sponsors several publications, starting since the early 1990s, that provide useful insights into how ecosystem resources can be valued (World Bank, 1992; Munasinghe, 1993; Felli et al., 2000). These studies, however, tend to focus on forests and water-related issues, including dams, coastal beaches, irrigation projects, etc., the reason being, apparently, that these elements constitute, arguably, the most visible and, perhaps, the most useful of the renewable environment resources.

As scientific knowledge of environmental resources and their services improves, new financial opportunities emerge. For example, the importance of tropical rainforests in protecting the ozone layer has only recently become appreciated, which explains, probably, the demand by developing countries for monetary compensation from the industrialized world for their tropical rain forests (Note 1). Further to this, fuller understanding of environmental resource uses in the rural economy has led economists to begin to re-evaluate the extent of rural poverty and inequality in developing countries (see, for instance, Cavendish, op. cit. on Zimbabwe).

\subsection{Environmental Resources as 'Global Commons'}

The natural environment, including its renewable components, has often been described in the literature as representing common property resources-alternatively, 'commons property', 'common pool resources', 'open-access property', etc,so-called because they belong 'at once to everyone and no one' (The Economist $23^{\text {rd, }}$ April (2005), p. 11; see also Black (2002, p. 67); Ostrom (1991); Ostrom and Walker (1994); Kebede (2002)). Their exploitation or use is open to all in a country or community at no charge, so that nobody is excluded from their use. So for common-pool resources or global commons barring unwanted users is difficult to enforce (exclusibility principle;) they are thus unclaimed public domain with no private property rights over them. Common-pool resources are, therefore, similar to public goods, the difference, however, being that, in certain circumstances, the use of a common-pool resource by one person will subtract the amount available to other users (the substractibility principle). Examples of global commons or common-pool resources would include: the atmosphere (air); fisheries resources at sea, streams and lakes; waters in lakes, rivers and streams; forests and fossil fuel reserves, etc. - these, indeed, represent 'mankind's vast inheritance of shared natural resources' available to all inhabitations in a society at zero charge.

However, not all forests would quality to be classified as global commons in the sense of having no private property rights over them (in the manner the atmosphere (air) for instance can be classified). Forests may be classified into four categories. The first is forestland that has become accessible and is adjacent to the local market (for production of marketed or commercial goods) or to the subsistence households (for non-market consumption goods). Such forestland often is highly valued agricultural land with secure property rights; it gradually gives way to harvested forestland and eventually to unclaimed open-access natural forest (Hyde et al., 1996).

Thehistorical origin of the global commons concept traces to the British Industrial Revolution era of the 1700s. 
As the latter began to unravel, cowsstill would graze on the commons in many villages in England and its American colonies (Perkins et al., 2001, pp. 198-9). The essence of a village commons was open access, free of charge, to any member of the village. The first villages to take advantage of open access would have ample grazing for their livestock; their only cost being the time it would take to herd their animals to the commons, allow-them to graze, and herd them back home. But the amount of land was fixed and soil fertility and climate limited the quantity of grass. With more villages using the fixed commons, the grass became sparse, so the animals took longer time to feed or, in the case of open rangeland, the herder was forced to travel father to find forage, so that everyone's costs rose.

The effect of rising average cost to each herder was to eventually discourage grazing on the commons. But none of the new herders had to pay the rising costs to each other of the previous entrants and more grazing took place than the commons carrying capacity would sustain, which was to the disadvantage of the village as a whole. Eventually, overgrazing exhausted the commons as a useful source of feed.

The dilemma of the commons is a widespread phenomenon, applicable to any (limited) resources to which access is unlimited by fees or regulation. Grazing on open range, whether in the African Savanna or elsewhere, has the same outcome: ultimate degradation or destruction of the resource. For example, open access to tropical forests for logging or access at fees well below the social cost results in over extraction and destruction of the native forests in Brazil, Ghana, Nigeria, and many other tropical countries (Note 2). Similarly, open access to fishing grounds in the North Atlantic, in Peru's Pacific waters, and in some inland lakes in Africa (e.g. the Lake Chad in West Africa (Note 3), and Lake Victoria in East Africa) already has depleted fish stocks beyond their ability to regenerate. Briefly, the concept of commons implies that there is no 'exclusion' principle so that the resources in question are shared freely (without any price of access) by all inhabitants in a community. Because there are zero user prices to exploit commons property, there is a tendency to overexploit them or abuse them or exploit them far beyond their carrying capacity. An ecosystem's carrying capacity is the maximum stress that it can absorb without changing to a vastly different state. Ecosystems are endemically subject to natural shocks and surprises such as fires, floods, storms, earthquakes, droughts, etc. Ecosystems, however, possess self-organizing and self-regenerating ability which determines their capacity to respond to such shocks. On the other hand, overexploitation of a natural resource will undermine its self-organizing ability which could lead to serious environmental degradation-e.g. biodiversity loss, to which we now turn.

\subsection{Biodiversity Loss}

Biodiversity loss, referring, as already noted, to irreversible loss of certain categories of animal and plant species, is, perhaps, the most important manifestation of the ecological crisis. In the last eight decades or so some 40 percent of animal species have become completely extinct in the industrialized world and another 660 species are endangered (Volkov, 1985, p. 96; Dobson, 1992; Hanski, 2005). The number of the species on earth has never been ascertained though; an estimated 5-100 million have been put up in the literature. According to the United States National Academy of Sciences (1998), a typical 10-square kilometer of pristine rain forest may contain as many of 125 species of mammals, 100 species of reptiles, 400 species of birds, 150 species of butterflies (see also Toby (1996)). What causes biodiversity loss? The literature identifies causes: market failure; government economic policy; and poor or inadequate information on functions of ecosystems.

\subsubsection{Market Failure}

This is the most commonly cited factor in the economic literature, whereby it is argued that the interplay of market forces-deemed grossly imperfect - does not secure the economically optimal balance of habitat conversion and its conservation. Such 'market failure' can originate in three factors.

First, there is the pervasive ill-defined, disputed or non-existent property rights problem. Recall the free-access or common-pool character of renewable ecological resources, whereby there exist no enforceable mechanisms to exclude anybody from using renewable environmental resources, which leads to their overexploitation. The second is that there exist missing or incomplete markets for ecological resources. Biodiversity and genetic resources are known to be broad international values conferred by highly specialized and generally local forest or aquatic resources. Although there is some evidence of an evolving international market for the protection of genetic resources-especially those that go into pharmaceutical research and biotechnology-this market is yet grossly thin, and the resource values of species often need to be protected with specialized management criteria or in specialized local forest reserves or some local specialized habitat. There is considerable difficulty in arranging secure property rights for specialized habitats, more so because neither flora nor fauna obey property boundaries. But it is pretty difficult, if not impossible, to ensure that a particular animal or plant species is confined to a particular locality so that other agents are excluded from using it. Biodiversity protection demands 
special land-use management that is more complex than fences and permanent restrictions on forest reserves and national packs (Hyde et al., 1996).

Third, market failure can originate in externalities which fail to capture the environmental benefits of resource conservation-such as, for instance, failure to impute the costs of biodiversity losses to transport systems or water pollution from agricultural production. Recall that externalities are benefits that accrue to society as a whole (external economies) or costs that accrue to society (external diseconomies) but cannot be internalized by the private individuals undertaking the activities. A private farmer, for instance, may be unwilling to undertake costly changes in farming technology that are deemed beneficial to biodiversity since other farmers and not necessary the farmer himself, will benefit from those changes.

\subsubsection{Government Economic Policy}

These can, and do indeed, have adverse side effects on biodiversity. Price controls and subsides in agriculture, urban development, water provision, transport, energy, etc. these distort the costs of the exploitation of environmental resources and, hence, leading to their degradation. Exchange rate devaluation during the structural adjustment programmes (SAPs) of the 1980s aiming to promote agricultural export incentives had the unintended effect of pushing farmers in Sub-Saharan Africa to exploit land and forest resources in unsustainable ways (Lopez, op. cit; Cromwell \& Winpenny, 1991; Reed, 1992).

\subsubsection{Poor Information on Functions of Ecosystems}

This gives rise to sub-optimal and unsound policy choices manifested in offering 'perverse incentives' which encourage behaviour that leads to degradation of natural resources. Scientists point out that ecosystems undergo 'irreversible collapse' (a situation whereby an environmental resources that has been impaired cannot be replaced in the future by another asset that provides equivalent services-e.g. depletion of the ozone layer by GHG emissions) when certain thresholds of change are attained. But knowledge of such thresholds is, at best, poor among private agents in developing countries, although it is of vital importance in designing biodiversity policy.

\section{Renewable and Non-renewable Resources}

The literature conceptually divides environmental resources into two categories: renewable and non-renewable -depending on whether they are depletable (limited in supply by nature and thus exhaustible) or non-depletable (available for use on a continuing basis).

\subsection{Renewable Resources}

Renewable ecological resources, as just stated, refer to those natural resources which are available for use on a continuing basis-e.g. the earth's atmosphere, including the air, solar energy, the land and soil, fish and plant populations, etc. In contrast, there are non-renewable or depletable resources, which are used up when used at all, and must definitely ultimately become exhausted-e.g. coal, oil, gas, inland lake, etc. It is noted, however, that there is difficulty in establishing whether certain environmental resources are renewable, which may depend on the intensity of use. A good example may be cited in underground water resources which are renewable if pumping is restricted to what is replaced by rainfall, but can be destroyed by overexploitation, leading to drying up or replacement of fresh water by sea-water. Some environmental resources which are in principle non-renewable or depletable - e.g. iron ore - in fact exist in such large reserves that any possible depletion date seems rather remote.

To return to renewable resources, most environmental resources are renewable resources: they can regenerate themselves over time, given certain conditions, of course. Forests or open rangelands reproduce themselves each year. Fish breed new stocks; wide life replenishes its herds; and forests reseed themselves. Air and water cleanse themselves of pollutants through biological, chemical, or mechanical transfers. Provided annual harvests do not exceed the annual growth of the stock, it is possible to exploit renewable ecological resources sustainably-the difference between the rate of harvest and the rate of growth being called the rate of depletion (see for instance, Tietenberg, (2000)) Indeed, the faster these resources can be replenished, the greater the rate of economic growth that can be sustained indefinitely. Three questions arise then in respect of renewable resources. First, what constitutes the maximum sustainable exploitation? Second, what is the economically optimal exploitation? And, third, what is the danger of over-exploiting the resources to the point of irretrievable loss or extinction? These questions can be answered using the example of fisheries in an open access lake.

\subsubsection{Sustainable Exploitation of Renewable Common Resources}

When (commercial) fishing begins in a lake, the fish can replenish their stocks more rapidly, and the sustainable 
catch increases, given that fish feed is made available. But as the fishing effort increases (more fisherman enter the lake), the fish stocks may not be replenished as rapidly as the rate of increase in fishing effort, which results in decline in the fish stocks as well as the sustainable catch. As fishing effort continues to grow (as the number of fishermen/boats in the lake continues to grow), the fish stocks may be so small or so scattered that reproduction cannot replace the catch at any level, which leads to extinction. The fisheries model provides a good illustration of the common resource problem. Recall that with the village commons, it was assumed that more entrants increase the costs for all. In the case of the fisheries, even if the costs of operating a boat are constant (the same per boat), the catch per boat, and hence fishermen's revenue, fall. The lesson here is that where there is open access to environmental resources or where natural resources is not effectively controlled, as is the case in developing countries, generally stocks cannot be maintained and extinction becomes a reality.

\subsection{Non-renewable Environmental Resources}

Non-renewable resources, as already hinted, refer to depletable resources - socalled because such resources are used up when used at all, and must eventually get exhausted in their supplies. Non-renewable resources are thus fixed in their supply (by nature) and are thus not unlimited in availability. Perfect examples are crude oil, coal, gas, etc. Fossil fuels are not unlimited in supplies; once extracted and used up the stocks of fossil fuels are not replaceable. Non-renewable resources can be destroyed by over-extraction, leading to exhaustion. In sum, non-renewable resources are depletable resources, existing in quantities with a finite life span. Earlier, we contrasted non-renewable resources with renewable resources which are available for use on a continuing basis-e.g. solar energy.

\subsubsection{Marketed Non-renewable Resources}

Logically, for non-renewable resources increases in consumption implies a reduction in available stocks. Economic development experience, however, gives little support to the hypothesis that marketed non-renewable resources - e.g. minerals; are becoming scarce in the economic sense because potential or actual shortages are always reflected in higher or rising market prices, which provide incentives to discover new sources of supplies and increase reserves, improve efficiency, find substitutes, and make technological innovations. A perfect example here is rising energy prices in the 1970s onward in the wake of OPEC-inspired price increases. Between the early 1970s and 1981 crude oil prices rose from less then $\$ 2 /$ barrel to $\$ 44 /$ barrel; in the 1980 s prices were stable at around \$20/barrel; as from the 1990s through the late 2008 prices rose sharply exceeding $\$ 100$ before tumbling in the wake of the on-going global economic meltdown. These price increases have provided incentives for exploitation of 'marginal fields', conservation and innovation of energy-saving devices apart from discovery of substitutes in synthetics, solar energy, etc.

Currently, world energy demand is growing rapidly. The latest forecast (available to the authors) by the International Energy Agency (IEA) shows global energy demand, under current policies, increasing by more than 60 percent from 2004 to 2030. The IEA concludes that global primary resources are adequate to meet projected demand increases: proven reserves of gas, oil, etc far exceed cumulative projected consumption and more reserves are likely to be added during the projection period (Saghir \& O' Sullivan, 2006).

Rather than decline in supply, marketed non-renewable energy and raw-materials have, indeed, increased in supply. So the problem is not how to increase supplies but, rather, how to manage the rents accruing from them to finance structural transformation; as well, the 'side effects' associated with their extraction and consumption pose environmental problems. The latter, however, do not come under the purview of the present paper.

\section{Valuing Environmental Resources: Goods and Services Provided by Ecosystems}

Many environmental resources, as noted earlier, provide a flow of services to producers and consumers over time. Put differently, ecological resources serve both as production inputs and final consumption goods. Ecological systems, beyond providing food and production inputs, control floods, filter pollutants, assimilate waste, pollinate crops, maintain a genetic library, preserve and regenerate soils, operate the hydrological cycle, and maintain the gaseous composition of the atmosphere. The tropical rainforests for instance contain and supply most of the plant species which provide essential ingredients in pharmaceutical preparations (see, for instance, Ibe and Nwafo 2005 on Southeastern Nigeria). Forests, swamps or 'wetlands' provide essential environmental services: they are known to filter and purify water, and act as reservoir to capture rain and melting snow. 'Wetlands' lie mostly in the tropical and semi-tropical regions, between $30^{\circ}$ North, $30^{\circ}$ South of the Equator, a zone whichincorporates much of Asia and the Pacific, most of Africa, and Central and South America. 

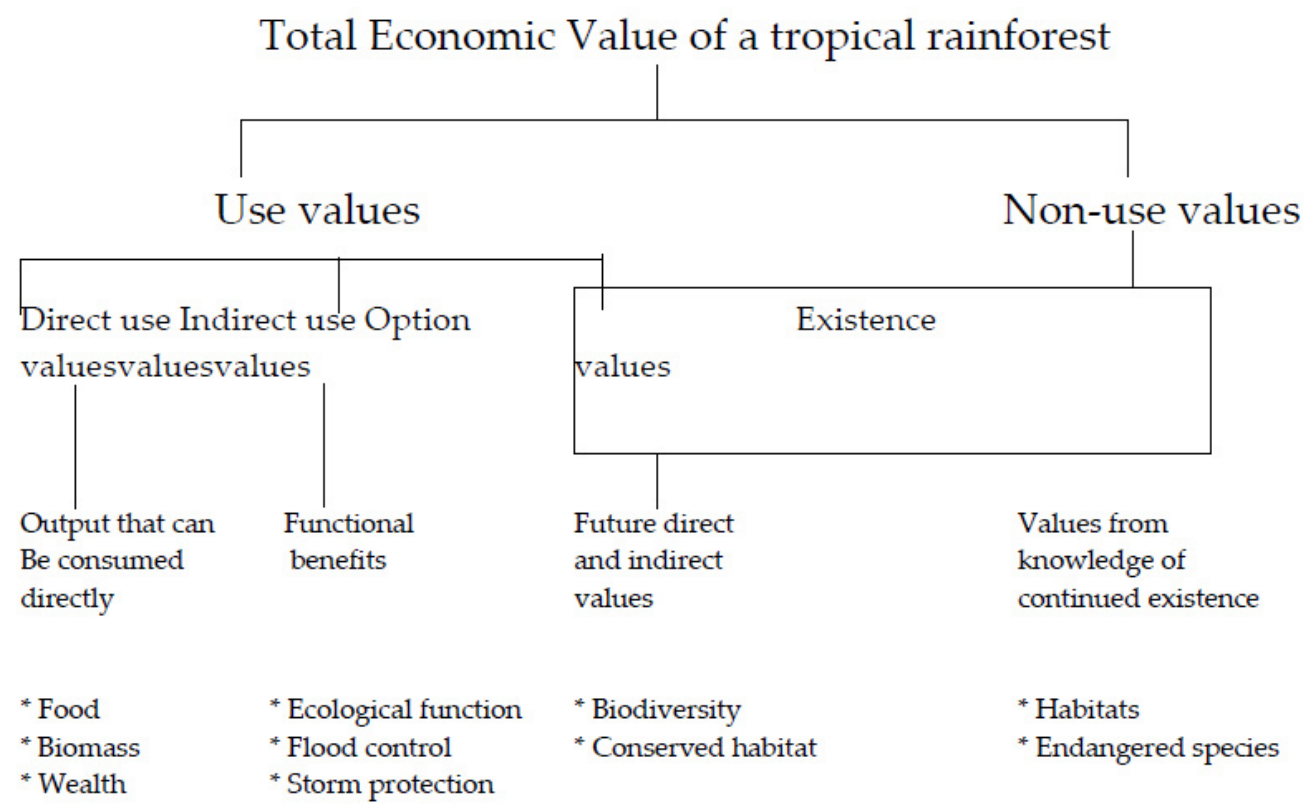

Figure 1. Economic Values Attributed to Environmental Resources (with Examples drawn from a tropical rainforest)

Source: Adapted from Munasinghe (1993; figure 3.1, p. 22).

\subsection{Tropical Rainforests: Environmental Functions}

Figure 1 conceptualizes the total economic values that can accrue from an environmental resource, drawing examples from tropical rainforests. Thus the total economic value of an environmental resource can be conceptually broken into two broad categories: use-values (outputs or services that can be consumed directly and indirectly) and non-use-values (Munasinghe op. cit.). For instance, tropical rainforests are a vital source of livelihood for rural populations (see Cavendish, op. cit.; Falconer \& Arnold, 1989; Falconer, 1990). Apart from serving as a direct source of food, rainforests are a source of timber, bark, saps, and pharmaceuticals (Ibe and Nwafo, op. cit.).

The indirect use-values of tropical rainforests come in the ecological services they provide: they influence local and regional climates, preserve soil cover on site, and in the case of watersheds, protect soil downstream from floods. Earlier studies show that the social value of forests (e.g. the ecological functions-see figure1) usually exceeds the direct use-value sometimes by a considerable margin (see, for instance, Anderson, 1987).

Mangrove rainforests provide an example of an ecosystem whose social benefits/values usually exceed the direct use value (Note 4). The services and functions they render to society as a whole are hardly appreciated, which has led to their destruction in many countries.

Mangrove rainforests occur in coastal areas in the tropics where waters are shallow and river deltas receive suspended sediment (mud)-often termed coastlands. The mangrove rainforests of the Niger Delta in Nigeria are the largest in the world covering some 11,700 $\mathrm{km}^{2}$ (Muoghalu, 2007). Mangrove prop-roots trap sediments from ebb and flood tidal currents, gradually extending land seawards; mangrove forests commonly consist of several shoreward belts of red, black, and white mangroves which constitute highly productive marines and estuarine ecosystems. As just noted, although society derives, directly or indirectly, immense benefits from the ecological services of mangrove rainforests they are hardly appreciated in policy and planning circles.

It is noted that primary productivity in estuaries may be twenty times higher than in the deep sea and ten times higher than in near-shore waters or deep lakes. Mangroves generate a large volume of degradable waste (leaves, stems, and the like) called detritus, the primary energy source for tropical coastal marine ecosystems. Colonies of microscopic life feed on detritus and are in turn consumed by estuarine species-shrimp, some fish, and small crustaceans, whichserve as forage for birds, predatory fish, and eventually human beings.

Other 'free' services are provided by mangroves, including storm protection, erosion control, wastewater cleanup, and areas for educational and leisure activities, as well as many direct products (fuel, construction 
timber) and indirect products (food from fish, shrimp, and birds). Moreover, mangroves are a renewable resource-reproducing and regenerating themselves at no cost; sustainable yields of fish and timber can be harvested on a continuing basis provided the ecological processes governing the mangrove system are not over exploited and destroyed.

\section{Environmental Accounting: Ecological Resources as National Wealth}

More recent literature centered around the notion of sustainable development (see section 6) has developed a framework for so-called environmental accounting whereby overall national wealth or capital assets is meant to incorporate not only produced capital (machines, plant, infrastructure, etc.) and human capital (knowledge, work experience and skills inhering in a nation's workforce) but, also, natural capital (forests, soils, rangeland, beaches, etc.) (Pearce \& Warford, 1993; Pearce \& Atkinson, 1993; Perkins et al., 2001, pp. 228-31; Aronsson \& Lofgren, 2010). It means that if an economy uses up natural capital in generating current output, as is often the case, then the economy's capacity to generate income will decline in the future if the natural capital is not replaced. This replacement can be done through higher investment in produced capital (including human capital), technological change must occur to boost productivity of all produced capital, or both must be done. Only by so doing can the economy create capacity to keep its consumption level or income per capita from declining over time-which is a key test for sustainable development, to which we return in section 6 .

This suggests an alternative, if partial, criterion for sustainable development: the maintenance of the total capital stock, including produced and natural capital stocks. The depletion of natural capital must be compensated for by net investment in produced capital. It means, therefore, that sustainability can involve the depletion of natural resources and the eventual relative decline of the natural capital base (farming, fishing, foresting, mining, petroleum and other extractive industries rooted on natural resources). As the latter decline, the non-natural resources dependent industries, including manufacturing, utilities, construction, finance, transportation, telecommunications, and the various services industries (education, health, finance, etc.), must also grow. Indeed, this structural transformation is what economic development is all about. Perkins et al. (2001, p. 288) thus conclude:

'When an economy develops from a natural resources base, the net benefits or rents from the primary sectors provide much of the finance for secondary and tertiary industries. And some of the finance may go into research and development of new technologies that will increase productivity ...'

It should be stressed that this transition from natural capital to produced capital, does not provide a rationale for wanton exploitation of natural resources. On the contrary it suggests or demands that natural resources be exploited efficiently. However development experience has shown that the substitution of produced capital for natural capital in the course of economic development may not turn out to be inefficient; besides, this transformation process is often disrupted which undermines sustainable economic development.

\subsection{Environmental Accounting}

The concept of sustainability as the efficient and continuous transformation of natural resources into produced capital can be incorporated into the national accounting framework (see Perkins et al., op.cit). We define gross national (or domestic) product (GNP or GDP) as the sum of value added in the production of finished goods and services in an economy. The concept of GNP makes no allowance for the depreciation or consumption of (existing) capital stock, hence he adjective gross. Another income concept, net national product (NNP), refers to GNP less the depreciation of produced capital (Note 5) (Dm):

$$
N N P=D N P-D m
$$

NNP is an appropriate measure of the resources available to the economy to meet its consumption needs once allowance has been made for capital depreciation. Given that GNP consists of consumption C and national saving S, then:

$$
N N P=C+S-D m
$$

As long as national saving equals or exceeds depreciation consumption is less than net product and can be sustained indefinitely. Sustainable development means, in effect, that the stock of capital complimented with labour generates NNP each year; if saving is enough to take care of replacement of used up capital, development becomes sustainable.

We need, therefore, to obtain a measure of the stock of natural capital and its depletion (Dn) to include in net product, which is called adjusted net national product (ANNP):

$$
A N N P=G N P-D m-D n=C+S-D m-D n
$$


ANNP has the same implication as NNP: if enough saving is made each year to takecareof Dm and Dn, the economy can sustain its level of consumption. Put differently, the basic sustainability criterion is that net national saving (NNS) must be positive (-i.e. NNS $>0$,), where NNS is measured as:

$$
N N S=S-D m-D n
$$

\subsection{Adjusted Net National Income: Empirical Example for Selected Countries}

The empirical literature has produced estimates of ANNP based on the above framework, see Table 1. Note the high resource depletion Dn for Indonesia and Nigeria; these were more than balanced by high national saving rates so that NNS remained positive.

Table 1. Adjusted Net National Income for Selected Natural-Resource-Rich Countries

\begin{tabular}{lllllll}
\hline Country & GNP & Dm & Dn & ANNP=GNP-Dm-Dn & National Savings & Net national savings = NNS-Dm-Dn \\
\hline Costa Rica & 100 & 3 & 8 & 89 & 21 & +10 \\
Indonesia & 100 & 5 & 17 & 78 & 30 & +8 \\
Brazil & 100 & 7 & 10 & 83 & 21 & +4 \\
Philippines & 100 & 11 & 4 & 85 & 18 & +3 \\
Nigeria & 100 & 3 & 17 & 80 & 23 & +3 \\
Mexico & 100 & 12 & 12 & 76 & 17 & -7 \\
Malawi & 100 & 7 & 4 & 89 & 2 & -9 \\
\hline
\end{tabular}

Source: Perkins et al. (op. cit, table 6-3, p. 229). Citing World Bank, World Development Report 1994 (Table 9); and Pearce and Atkinson (op.cit, pp. 103-8.).

It should be noted, however, that both Dm and Dn are only approximations for most developing countries. For this reason, neither NNP nor ANNP has been used much in official estimates, and they have hardly affected policy discussions. The United Nations and the World Bank, however, are encouraging countries to begin incorporating natural resources and environmental assets into their stock of national wealth.

Dixon (1997) has produced estimates on the structure of stock of wealth by world regions. The Middle East (rich in petroleum resources), West Africa rich in tropical rainforests and South and South-East Asia (rich in flood plains for cultivating rice), in that order, have the highest share of natural capital in their stock of national wealth. In contrast, North America, Western Europe, and Japan and the East Asian newly industrializing countries (NICs) have low share of natural capital ( high share of produced capital) in their national wealth.

The Southeast Asian NICs approximate the textbook model of how natural capital can be converted into produced capital that leads to sustainable growth and development, which sets in motion forces that eventually limit the further depletion of natural resources. Rapid expansion of export- based agriculture (rubber, palm produce, rice, etc.) supported by government policies on land reform, investment in $\mathrm{R} \times \mathrm{D}$, physical infrastructure and fiscal incentives, generated rapid growth in exports and foreign savings to finance investment in export-based industrialization, which, in turn, facilitated labour mobilization and reallocation from rural to urban employments raising rural incomes and wages and further encouraging agricultural intensification (see also Hayami, 2001; and Harrold et al., 1996).

\section{Sustainable Development and the Natural Environment}

The notion of sustainable development grew out of the United Nations World Commission on Environment and Development (WCED 1987), otherwise known as the Brundtland Report. The notion of sustainable development is conceived as 'development that meets the needs of the present without compromising the ability of future generations to meet their own needs'. Rather than predicting greater environmental degradation and difficulties in a world of ever-declining natural environmental resource levels, the Brundtland Report foresees 'the possibility of a new era of economic growth, based on polices that sustain and expand the natural environmental resources base'.

The literature of the 1980s took off from this notion, expatiating on the idea that economic development requires a strong policy of protecting the environmental capital base as a component of the national wealth (see, for instance Pezzy, 1989; Pearce et al., 1989; Solow, 1986; Fay, 2012). More recent literature-particularly from environmentalists-goes further and separates out natural capital for special attention. This literature argues the position, that most forms of economic growth make demands on the environment, both by using (sometimes non-renewable) natural resources and by generating waste and pollution, which jeopardizes growth for future generations. The notion of sustainable development attempts to resolve this dilemma by insisting that economic 
policy decisions should have utmost regard for their possible environmental outcomes. In this way, the right kind of growth outcome-based on biodiversity, the control of environmentally unfriendly activity, and replenishment of renewable resources such as forests, fish stocks, etc. - is generated, and this can protect or even enhance the national capital base. Current economic development is then rendered compatible with investment in environmental resources for future generations. How to achieve this compatibility has posed serious difficulty for developing countries, generally, where the urge to achieve rapid economic growth is most felt.

\subsection{Relative Productivity of Natural and Produced Capitals}

A second point of debate concerns the relative growth-promoting capacity of natural and produced capitals. Environmentalists tend to argue that fossil energy resources and other natural resources like wilderness areas, game reserves, pristine rainforests, etc. are very special kinds of capital assets that should be preserved so that we can attain sustainable development. Economists, on the other hand, tend to view sustainable development quite differently: they regard natural resources as a special category of capital-along with produced capital, including human capital.

Both economists and environmentalist agree that our generation should bequeath an adequate stock of capital assets for the future generations, with economists arguing that economic development necessarily results in produced capital substituting for natural capital in the long run; that further generations will benefit more from larger stocks of produced capital such as additional scientists and engineers, medical personnel, better laboratories and more efficient transportation, etc. than from larger stocks of natural capital such as crude petroleum, gas, coal, etc. Briefly, economists would argue that sustainable development is better understood in terms of substitutability of natural capital and produced capital (see Neumayor, 2010; Atkinson, Dietz \& Neumayor, 2008; Hamilton et al., 2008).

Figure 2 illustrates this process using the production isoquant or production indifference curve, where produced capital (proxied by human capital $\left(\mathrm{K}_{\mathrm{H}}\right)$ ) on the vertical axis and natural capital $\left(\mathrm{K}_{\mathrm{N}}\right)$ on the horizontal axis are two kinds of capital that would be required to attain a certain level of future output $\mathrm{Q}$, holding other inputs constant. Output $\mathrm{Q}$ can be produced at point $\mathrm{C}$ with a conservationist policy emphasizing reducing fossils energy consumption currently (by present generation) consuming much oil, gas, coal, etc; Q might be produced at point B using a low natural capital intensity and high produced capital intensity.

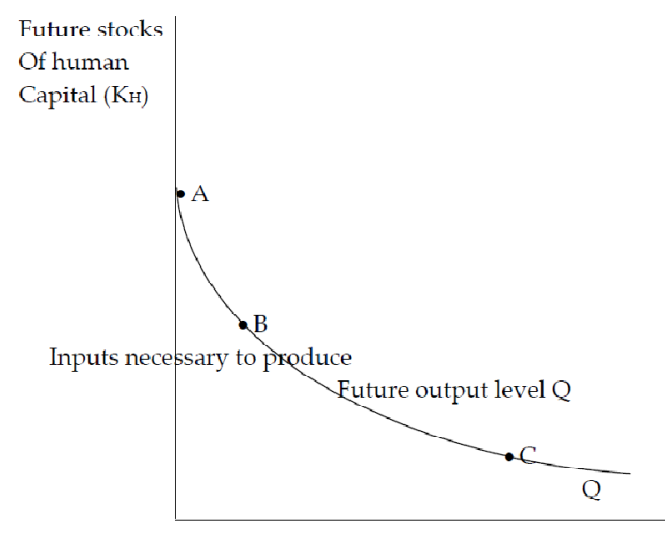

Future stocks of natural capital ( $\left.\mathrm{K}_{\mathrm{N}}\right)$

Figure 2. Substitutability of natural capital and produced capital in development

Either of these strategies appears feasible; and a more desirable one is that generating a higher consumption both for present and future generations.

What about producing at point $\mathrm{A}$, where our isoquant intercepts the vertical axis indicating that $\mathrm{Q}$ can be produced only with produced capital and no natural capital? Is this a feasible alternative? Yes, with the greater scientific and technological knowledge represented by point A, society can develop and introduce substitute technologies like clean coal or solar energy to substitute completely for exhausted fossil energy. Point A indicates that in the long run, fossil fuels are not essential and can be completely replaced by produced capital. This is an optimistic view much in line with (the neoclassical) perspective on economic growth on which factor combinations change in response to factor scarcities. Point A scenario approximates the situation in the OECD economies or so-called post-industrial economy of Western Europe, North America and Japan where substitute technologies are being innovated to attempt to reduce the consumption of fossil energy. 


\subsection{Is the World Facing a Malthusian Trap?}

Modern economic development literature is more or less optimistic that natural capital is substitutable (by produced capital), so that growing natural resource scarcity itself cannot constitute a constraint on long-run development but would rather act as the main motivation to changes in behaviour (on how to manage resources) and technology. In contrast, classical economics-especially the Ricardo-Malthus strand-was not particularly optimistic in this regards. But the classic scenario regarded or assumed natural resources as fixed (by nature) and exhaustible in the longrun, and non-substitutable by produced capital. Unlike modern economics which operates on the assumption of technological change permitting substitutability between inputs in the production function, classical economics operated on the notion of complementarity between inputs: specifically, capital and labour were considered to be the variable inputs combined with land (assumed fixed in supply) in fixed proportions in the classical production function.

Specifically, the classical scenario was premised on the thesis that rapidly growing human populations would exhaust the earth's capacity to produce the means of subsistence or food (by using up available agricultural land assumed fixed in supply), until rising death rates and falling birth rates harshly would keep population in check. This Malthusian trap thesis remains influential today, although current focus has shifted focus from land and agriculture to all natural resources and the global environment.

Both historical and current evidence disprove the Malthusian trap thesis predicting an apocalyptic development meltdown.

Indeed, the Malthusian trap has been avoided, historically, in several major ways. First, technological change discounted in the classical scenario has helped to increase the productivity of landnote the effect of the Green Revolution in pushing back the threat of famine in high-population countries of Asia-specifically, India, Indonesia etc. Second, resource scarcities have provided the major incentive to search for substitute technologies logically, for non-renewable resources increases in consumption implies a reduction in available stocks. Economic development experience, however, gives little support to the hypothesis that marketed non-renewable resources- e.g. minerals, energy, etc. are becoming scarcer in an economic sense because potential or actual shortages are always reflected in higher or rising market prices, which provide supply incentives to discover new sources of supplies and increase reserves, improve efficiency, find substitutes, and make technological innovations.

A perfect example here is the rising energy prices since the 1970s in the wake of OPEC-inspired hikes in crude oil export prices: between the early 1970 s and 1981 , oil prices rose from less than $\$ 2 /$ barrel to $\$ 44$; in the 1980 s prices were stable at around $\$ 20 /$ barrel. Since the 1990 s, crude oil prices have risen rapidly, exceeding $\$ 100 /$ barrel by late 2012 (see Rozhnov, 2012).

These price developments have provided incentives for exploitation of marginal fields, conservation and innovation of energy-augmenting technologies in automobiles and home devices apart from discovering of substitutes in synthetics, solar energy, etc. Besides, man-made fuels such as ethanol derived from plants (mainly corn), or diesel 'conjured from coal and gas' hold out the promise of unlimited supply.

So the problem confronting global policy now is not how to increase marketed supplies but, rather, that the un-marketed side effects associated with their extraction and consumption has become serious problems. In the case of fossil fuels -e.g. crude oil, natural gas, coal, etc-the real issue is not a potential shortage but the environmental effects associated with their use particularly local air pollution and carbon dioxide emissions. Similarly, solid mineral extraction generates pollution and destruction of natural habitats.

A relevant question to ask, however, is whether the processes of technological change, discovery of substitutes, etc. can continue indefinitely to postpone the Malthusian resource trap indefinitely. Even though current global trends in population growth rates show a slowing down the rates remain high enough to expect a doubling of the world's population by 2050 or so (World Bank, 1992, p. 26). Most of the growth recorded in world population since the postwar II decades has originated in populous Asia and Latin America. A rising share of this population will aspire to the high consumption standards of the industrial middle class in the OECD countries, which suggests more intensive demands on resources and associated pollution, a trend now observed for China. As a result, the world's stocks of non-renewable fossil fuels will become depleted and the environment gets more polluted.

\section{Conclusion}

Current explicit recognition of environmental resources as a legitimate component of national wealth suggests that environmental resources should be accumulated, nurtured and protected in much the same way as produced 
capital. But environmental resources constitute inputs into the production of goods and services just like produced (physical and human) capital; they can be-and usually are-depleted and degraded in the course of economic development just as produced capital is. It is also through natural growth of renewable resources that environmental resources can be regenerated and augmented, just as investment replenishes the stocks of produced capital.

A key economic characteristic of environmental resources is that many of these resources are renewable resources and have the features of public goods-accessible to all in a community/country at no charge, so that excluding unwanted users is difficult. Consequently, such resources are open to overexploitation to the point of extinction in many cases, which imposes costs on society as a whole. National and international policy interventions to grapple with the latter are on-going. A future paper will attempt to survey the issues connected with this problem.

\section{References}

Anderson, D. (1987). The Economics of Afforestation: A case study in Africa. The Jeans Hopkins University Press.

Aronsson, T., \& Lofgren, K. (Eds.). (2010). Handbook of Environmental Accounting. Edward Elgar.

Atkinson, G., Dietz, S., \& Neumayer, E. (Eds.). (2008). Handbook of Sustainable Development. Edward Elgar.

Belli, P., Anderson, J. R., Barnum, H. N., Dixon, J. A., \& Tan, J. (2000). Economic Analysis of Investment Operations: Analytical Tools and Practical Applications. Washington D. C., The World Bank.

Bergstrom, J. C., \& Randall, A. (2010). Resource Economics (3rd ed.). Edward Elgar.

Black, J. (2002). Oxford Dictionary of Economics. Oxford-New York: Oxford University Press.

Bosetti, V., Gerlagh, R., \& Schleicher, S. P. (Eds). (2009). Modelling Sustainable Development: Transition to Sustainable Future. Edward Elgar.

Bowen, A., Romani, M., \& Stern, N. (2010). Challenge of the Century. Finance and Development, March.

Cavendish, W. (1999). Poverty, Inequality and Environmental Resources: Quantitative Analysis of Rural Households. Working Paper Series WPS/99-99, Centre for the Study of African Economies, Oxford University.

Chomitz, K. M., \& Kumari, K. (1998). The Domestic Benefits of Tropical Forests: a Critical Review. The World Bank Research Observer, 13(1), 13-35. http://dx.doi.org/10.1093/wbro/13.1.13

Coe, M. T., \& Foley, J. A. (2001). Human and Natural Impacts on the Water Resources of the Lake Chad Pasin. Journal of Geographical Research, 3349-3356.

Cromwell, C., \& Winpenny, J. T. (1991). Has Economic Reform harmed the Environment? A Review of Structural Adjustment in Malawi. London: Overseas Development Institute. (ODI)

Dasgupta, P., \& Meiler, K. (1991). The Environment and Emerging Development Issues. In Stanley Fischer, Denis de Tray and Shekhar Shah (Eds.), Proceedings of the World Bank Annual Conference on Development Economics 1990. Washington D. C. The World Bank.

Dike, E. (2007). Environmental Problems in Economic Development: a Review of Key Issues. In E. E. Udoye et al. (Eds.), Environment and Conflicts in Africa: Issues and Problems (chap. 3). Enugu: Frefabcey Investment Ltd.

Dixon, J. A. (1998). Comment on "Environment, Poverty, and Economic Growth," by Karl-GoranMaler. In Boris Pleskovic and Joseph E. Stiglitz (Eds.), Annual World Bank Conference on Development Economics 1997 (pp. 277-81). The World Bank Washington D. C.

Dobson, T. (1992). Loss of Biodiversity: An International Environmental Policy Perspective. Heinonline; retrieved 14/08/2012

Falconer, J. (1990). The Major Significance of "Minor" forest products: The Local Use and Value of Forests in the West African Humid Forest Zone. Rome: United Nation Food and Agricultural Organization.

Falconer, J., \& Arnold, J. E. M. (1989). Household Food Security and Forestry: An Analysis of Socio-Economic Issues. Rome: United Nations Food and Agricultural Organization.

Folmer, H., \& Tietenberg, T. (2006). The International Yearbook of Environmental Resource Economics 2005/2006: A Survey of Current Issues. Edward Elgar. 
Hamilton, K., \& Atkinson, G. (2008). Wealth, Welfare and Sustainability. Edward Elgar.

Hamilton, K., \& Fay, M. (2009). A changing Climate for Development. Finance\& Development December, $10-12$.

Hanski, I. (2005). Landscape Fragmentation, Biodiversity Loss and the Societal Response. (National Center for Biotechnology Information (NIH). www.ncbi.hlm.nih.gov. retrieved 8/14/2012.

Harrold, P., Jayawickrama, M., \& Bhattasali, D. (1996). Practical Lessons for Africa from East Asia in Industry and Trade. World Bank Discussion Papers, no. 310, The World Bank, Washington D. C. http://dx.doi.org/10.1596/0-8213-3484-0

Hayami, Y. (2001). Ecology, History, and Development: A Perspective from Southeast Asia. The World Bank Research Observer, 6(2), 169-98. http://dx.doi.org/10.1093/wbro/16.2.169

Hyde, W. F., Amacher, G. S., \& Magrath, W. (1996). Deforestation and Forest land use: Theory, Evidence and Policy Implications. The World Bank Research Observer, 11(2), 223-48. http://dx.doi.org/10.1093/wbro/11.2.223

Ibe, A. E., \& Nwufo, M. I. (2005). Domestication of medicinal plants in Southeastern Nigerian? Africa Development, 30(3), 66-77. http://dx.doi.org/10.4314/ad.v30i3.22230

Ikegbunam, F. I. (2007). Bidiversity loss and crises in the Environment: Issues and the Options to man. In E. E. Udoyw et al. (Eds), Environment and Conflicts in Africa: Issues and Problems (Chap. 5). Enugu: Frefbay Investment Ltd.

Jones, B., \& Keen, M. (2009). Climate Policy in Hard Times. Finance \& Development, December, 7-9.

Kebede, B. (2002). Land Tenure and Common Pool Resources in Rural Ethiopia: a study based on fifteen sites. African Development Review, 14(1), 133-149. http://dx.doi.org/10.1111/1467-8268.00048

Lombory, B. (2009). Technology, Not Talks Will Savethe Planer. Finance \&Development, December, 13-14.

Lopez, R. (1992). The Environment as a Factor of Production: The Economic Growth and Trade Policy Linkage. In Patrick Low (Ed.), International Trade and the Environment. Washington D. C. the World Bank.

Lopez, R. (1998). The tragedy of the commons in cote d'lvoireAgriculture: Empirical Evidence and Implications for Evaluating Trade Policies. The World Bank Economic Review, 12(1), 105-31. http://dx.doi.org/10.1093/wber/12.1.105

Lutz, E. (Ed.). (1993). Towards Improved Accounting for the Environment. The World Bank: Washington D. C. http://dx.doi.org/10.1596/0-8213-2436-5

Maler, K. (1998). Environment, Poverty, and Economic Growth. In BorisPleskovic and Joseph E.Stiglitz (Eds.), Annual World Bank Conference on Development Economics 1997 (pp. 251-270). Washington D. C. The World Bank.

Mendelsohn, R., \& Balick, M. (1995). The Value of Undiscovered Pharmaceuticals in Tropical Forests Economic Botany, 4(2), 223-28.

Mortimore, M. (1989). Adapting to Drought: Farmers, Families and desertification in West Africa. Cambridge University Press. http://dx.doi.org/10.1017/CBO9780511720772

Munasinghe, M. (1993). Environmental Economics and Sustainable Development. World Bank Environment Paper no.3.

Muoghalu, L. N. (2007). Environment and Conflicts in Africa: Issues and Problems- focus on the Niger Delta Region of Nigeria. In E. E. Udoye et al. (Eds.), Environment and Conflicts in Africa: Issues and Problems (chap. 2). Enugu: Frefabag Investment Ltd.

Neumayer, E. (2010). Weak versus Strong Sustainability: Exploring the limits of two opposing Paradigms (3rd ed.). Edward Elgar.

Noble, I., \& Watson, R. T. (2006). Confronting Climate Change. In VinayBhargava (Ed.), Global Issues for Global Citizens. Washington D. C.: World Bank.

Noble, I., et al. (2005). Climate Change. In Ecosystem and Human Well-Being: Policy. Responses Washington D. C.: Island Press.

Onuoha, F. C. (2008). Saving Africa's Shrinking Lakes Through Water Transfer Projects: Reflections on the ProposedLake Chad Replenishment Project. Nigerian Journal of International Affairs, 3(2), 65-84. 
Ostrom, E. (1991). Governing the Commons. The Evolution of Institutions for Collective Action. Cambridge University press.

Ostrom, E., Gardner, R., \& Walker, J. (1994). Rules, Games and Common-pool resources. Ann Arbor: University of Michigan Press.

Pearce, D. (2009). Environmental Valuation in Developed Countries: Case Studies. Edward Elgar.

Pearce, D. W., \& Warford, J. J. (1993). World without End: Economics, Environment, and Sustainable Development: A Summary. Washington D. C. The World Bank.

Pearce, D. W., Barbier, E., \& Markandya, A. (1989). Sustainable Development: Economics and Environment in the Third World. London: Edward Elgar.

Pearce, D., \& Atkinson, G. (1993). Capital Theory and The Measurement of Sustainable Development: An $\begin{array}{llllll}\text { Indicator of 'Weak Sustainability'. Ecological Economics, } & \text { 8, } & \text { 103-8. }\end{array}$ http://dx.doi.org/10.1016/0921-8009(93)90039-9

Perkins, D. H., Radelet, S., Snodgrass, D., Gillis, M., \& Roemer, M. (2001). Economics of Development (5th ed.). W. W. Norton and Company.

Pezzy, J. (1989). Economic Analysis of Sustainable Growth and Sustainable Development. Environment Working Paper, 15, World Bank Washington D. C.

Piazza-Georgi, B. (2002). The Role of Human and Social Capital in Growth: Extending our Understanding. Cambridge Journal of Economics, 26, 461-47. http://dx.doi.org/10.1093/cje/26.4.461

Reed, D. (Ed.). (1992). Structural Adjustment and the Environment. Boulder, Clo.: Westview.

Rozhnov, K. (2012). Oil Futures- Crude Prices Stable: DOE Data, Brent Rollover Eyed. The Wall Street Journal. August, 15.

Saghir, J., \& O'Sullivan, K. (2006). Towards a Sustainable Energy Future. In VinayBhargava (Ed.), Global Issues for Global Citizens. Washington D. C.The World Bank.

Samuelson, P. A., \& Nordhaus, W. D. (2005). Economics (18th ed.). Tata-McGraw-Hill Edition.

Sedjo, R. A. (1992). Property Rights, Genetic Resources, and Biotechnological Change. Journal of Law and Economics, 35, 199-213. http://dx.doi.org/10.1086/467250

Soderbaum, B. (1996). Revaluing Wetlands. The OECD Observer, 198(February/March), 47-50.

Solow, R. M. (1986). On the Intergenerational Allocation of Natural Resources. Scandinavian Journal of Economics, 88, 141-9. http://dx.doi.org/10.2307/3440280

The Economist $23^{\text {rd }}$ April. (2005). Environmental Economics: Are you Being Served? The Economist, London.

Tietenberg, T. (2000). Environmental and Natural Resource Economics (5th ed.). New York: Addison-Wesley.

Tobey, J. (1996). Economics Incentives for Biodiversity. The OECD Observer, 198(Feb/March), 25-8.

UNEP. (on line): United Nations Environment Programme. Impacts on Africa's Lakes: Case Studies Africa's Changing Lakes (on line)http:/na.unep.net/Africalakes/AecasDoenload/PDFs/Africas-chapter 3-0-Screen. Pd.

Vincent, J., \& Hadi, Y. (1991). Deforestation and Agricultural Expansion in Peninsular Malaysia. Harvard Institute for Internaional Development, Development Discussion Paper no. 396, September.

Vincent, J., \& Mohammed Ali, R. (1994). Natural Resources, Environment, and Development In Malaysia. An Economic Perspective' Unpublished Manuscript.

Volkov, M. I. (Ed.). (1985). A Dictionary of Political Economy. Moscow: Progress Publishers.

WCED. (1987). World Commission on Environment and Development, Our Common Future. Oxford University Press.

World Bank. (1992). World Development Report 1992: Development and the Environment. Oxford University Press.

World Bank. (1997). Expanding the measure of wealth: Indicators of Environmentally Sustainable Development. Environmentally Sustainable Development Studies and Monograph Series 17, Washington D. C.

World Bank. (2003). World Development Report 2003: Sustainable Development in a Dynamic World. Oxford University Press. 
World Bank. (2010). World Development Report 2010: Development and Climate Change. Washington D. C.: The World Bank.

\section{Notes}

Note 1. Give us the money or the forest gets it' is credited to United Kingdom environment minister Elliot Morley; quoted in The Economist April $23^{\text {rd }} 2005$, p. 79, as blackmail he received from developing countries.

Note 2. For insightful comments on this problem with regard to Nigeria, see Ikegbunam (2007) and Muoghalu (2007).

Note 3. See for instance Onuoha (2008).

Note 4. This section relies on insights in Maler (1998), Soderbaum (1996), and Chemitz and Kumari (1998).

Note 5. Depreciation of produced capital-referring to the expiration of the economic usefulness of produced capital assets-results from two sources: physical and functional factors. Physical depreciation involves normal wear and tear, deterioration and decay, and even loss through accidental destruction, through fire, war, etc. Functional depreciation involves inadequacy and technological obsolescence. In economies where technological change is rapid-e.g. the countries of the Organization for Economic Cooperation and Development (OECD)technological obsolescence tends to be rapid. 